\title{
Selection of Attachment Mutants during the Continuous Culture of Pseudomonas fluorescens and Relationship between Attachment Ability and Surface Composition
}

\author{
By J. HOWARD PRINGLE, ${ }^{1} \dagger$ MADILYN FLETCHER ${ }^{1 *}$ AND \\ D. C. ELLWOOD ${ }^{2}$ \\ ${ }^{1}$ Department of Environmental Sciences, University of Warwick, Coventry CV4 7AL, U.K. \\ ${ }^{2}$ PHLS, Centre for Applied Microbiology and Research, Porton Down, Salisbury SP4 OJG, U.K.
}

(Received 10 December 1982; revised 21 March 1983)

\begin{abstract}
A strain of Pseudomonas fluorescens that had been isolated from a freshwater source on a plastic substratum was grown in continuous culture in minimal medium. The 'adsubble' process (adsorptive bubble separation process) was found to foam-fractionate wild-type cells from the fermenter during flow conditions. This selection pressure favoured the enrichment of two major classes of mutant, both having cell surface characteristics fundamentally different from the wild-type. The wild-type produced very little extracellular polysaccharide, whereas a 'mucoid' mutant, found predominantly in the aqueous-phase, produced an alginate exopolymer. The second class of mutant was isolated from the walls of the fermenter and, like the wild-type, produced little exopolymer. This mutant, with crenated colony morphology, showed increased attachment to solid surfaces compared to the wild-type and mucoid cells when assayed for attachment to polystyrene surfaces for $2 \mathrm{~h}$. Outer-membrane protein, lipopolysaccharides and exopolysaccharides of the wild-type and both mutants were analysed. The results demonstrate the role of cell surface characteristics in the adaptability of the organism to micro-environments such as a solid/liquid or air/liquid interface or the aqueous phase.
\end{abstract}

\section{INTRODUCTION}

The attachment, or adhesion, of bacteria to solid surfaces has recently been recognized as an important process in their ecology. The maintenance of productive soils (Stotzky, 1980), the formation of communities on submerged surfaces in the aquatic environment (Marshall, 1976), and the virulence of many bacterial pathogens for animals (Walker \& Nagy, 1980) and plants (Dazzo, 1980; Lippincott \& Lippincott, 1980) all depend, in part, upon the attachment process. Economic implications of attachment have prompted studies of fouling-communities in aquatic environments, such as microbial films on heat exchangers (Meadows \& Anderson, 1979), oral communities causing dental caries (Gibbons \& Van Houte, 1980) and, more recently, control of immobilization of bacterial cells for industrial processes (Hollo et al., 1979; Venkatasubramanian \& Vieth, 1979). However, despite the recognized biological importance of these phenomena, little understanding of the underlying mechanisms has been achieved.

In this study, the role of cell surface components in the attachment of bacteria to a solid surface was investigated. A freshwater strain of Pseudomonas fluorescens that had been newly isolated from a freshwater source on a plastic substratum and tested for its ability to attach to a

$\dagger$ Present address: Department of Molecular Biology, University of Edinburgh, Edinburgh EH9 3JR, U.K.

Abbreriations: AA, alditol acetate; EP, exopolysaccharides; LPS lipopolysaccharides; PAAN, peracetylated aldononitrile. 
range of substrata (Pringle \& Fletcher, 1982) was used. In order to determine which cell surface components were involved, attachment mutants were isolated and analysis made of their extracellular polymeric substances and outer-membrane components thought to be involved in the non-specific attachment of bacterial cells to solid surfaces (Corpe, 1979; Costerton et al., 1978; Fletcher \& Floodgate, 1973; Rogers, 1980; Sutherland, 1980). The selection and enrichment of such mutants was achieved by incorporation of the 'adsubble' process into a continuous culture fermenter. The term adsubble processes is a contraction of adsorptive bubble separation processes and is defined as "those phenomena and techniques in which dissolved or suspended material is segregated within or removed from a liquid by adsorption or attachment at the surface of rising bubbles' (Lemlich, 1966, 1972; Karger, 1967). For colloidal material such as a bacterial suspension, if these bubbles form an overflowing or otherwise removable foam, facilitating the separation of the material, the process is called foam fractionation and is shown schematically in Fig. 1. Figure 2 shows how this principle was incorporated into the continuous culture system. A conventional fermenter design was used; however, by maintaining the liquid level using gas entrainment, an overhead overflow was found to selectively remove foam from the surface of the culture. Under these continuous culture conditions in $\mathrm{C}$ - or $\mathrm{N}$-limited minimal media, the wild-type was found to concentrate in the foam layer and was removed from the fermenter.

The selection pressure that resulted from this process favoured the enrichment of two major classes of mutant, both having cell surface characteristics fundamentally different from the original organism. These were identified by stable changes in the colony morphology when plated on to either minimal or complex solid media. This investigation examined these changes in cell surface characteristics in relation to the cell's attachment ability. Outer-membrane proteins, lipopolysaccharides (LPS) and exopolysaccharides (EP) of the wild-type and both mutants were analysed, following growth of each strain in batch culture. The outer-membrane proteins were analysed by SDS-PAGE, and component sugar analysis was carried out by GLC of suitable derivatives of the hydrolysates of LPS and EP extracted from each strain. The attachment of each strain to hydrophobic and hydrophilic polystyrene substrata was compared indirectly by measuring the absorbance of crystal violet stained cells attached to polystyrene and tissue culture polystyrene petri dishes.

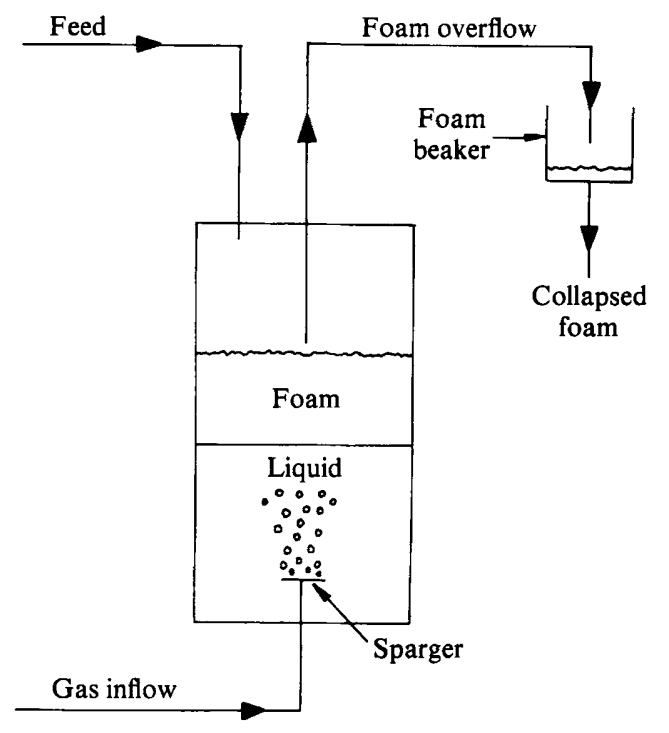

Fig. 1. A schematic diagram for foam fractionation. 


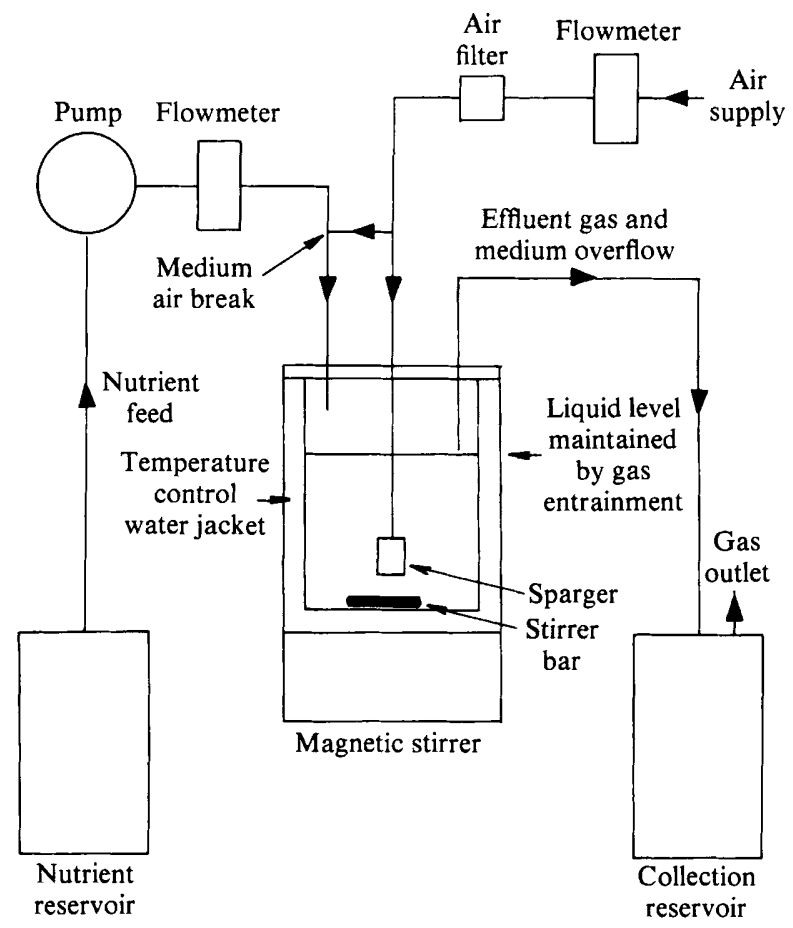

Fig. 2. The continuous culture equipment incorporating a foam fractionation system.

\section{METHODS}

Isolation and identification of the test organism. The test organism was isolated from a polystyrene sheet following immersion in fast running water at Baginton Weir, River Sowe, Coventry for $2 \mathrm{~h}$ (in situ $\mathrm{pH} 8 \cdot 1 ; 5 \cdot 5^{\circ} \mathrm{C}$ ). Further details of the isolation procedure may be found in Pringle \& Fletcher (1982). The test organism was identified as Pseudomonas fluorescens from the identification keys of Hendrie \& Shewan (1979) and King \& Phillips (1978). The tests included: oxidase (Kovács, 1956); incubation temperature, $5^{\circ} \mathrm{C}$ (up to 3 weeks), $41^{\circ} \mathrm{C}$ (in nutrient broth incubated in a water bath) (Haynes \& Rhodes, 1962); extracellular hydrolases (gelatin, starch, casein, DNA); single carbon-source utilization performed with the simple basal medium of Palleroni \& Doudoroff (1972) containing ethanol, glucose, maltose or mannitol; pigment production on King's A and B medium (King et al., 1954); and antibiotic sensitivity tests determined by a disc (Oxoid) method on nutrient agar plates surface-seeded from a young ( $2-3 \mathrm{~d}$ ) broth culture, using the following agents: ampicillin (disc content $25 \mu \mathrm{g}$ ), carbenicillin $(100 \mu \mathrm{g})$, cephaloridine $(25 \mu \mathrm{g})$, chloramphenicol $(10 \mu \mathrm{g})$, colistin $(10 \mu \mathrm{g})$, erythromycin $(10 \mu \mathrm{g})$, gentamicin $(10 \mu \mathrm{g})$, novobiocin $(5 \mu \mathrm{g})$, penicillin (5 units), polymyxin B (300 units), streptomycin (10 $\mu \mathrm{g})$, sulphafurazole $(500 \mu \mathrm{g})$ and tetracyline $(50 \mu \mathrm{g})$.

Culture conditions. Pseudomonas fluorescens wild-type and adhesion mutants were cultured in a chemically defined medium described by Williams \& Wimpenny (1976). The carbon source was glucose $(0 \cdot 1 \%$, w/v) and the medium was adjusted to $\mathrm{pH} 7.0$ with $1 \mathrm{M}-\mathrm{NaOH}$. Batch cultures were grown in $250 \mathrm{ml}$ conical flasks at $15^{\circ} \mathrm{C}$ in an orbitally shaken incubator (150 r.p.m.). Growth was followed turbidimetrically and cells were harvested in lateexponential phase by centrifugation.

Continuous cultures were grown in a 1 litre Quick-fit (Fisons) glass-walled vessel with five ports. This was maintained at $15^{\circ} \mathrm{C}$ using a temperature-controlled water-jacket with a refrigerated cooler (Churchill). Moist air was sparged into the culture vessel at a flow rate of 1 litre $\mathrm{min}^{-1}$ and the culture was vortexed using a magnetic motor stirrer [Heidolph Drehzahl (makers), Scientific Industries Intrl, Loughborough, U.K. (suppliers)]. A constant volume was maintained by gas entrainment (shown in Fig. 2) with an overhead overflow. The nutrient feed was delivered using a peristaltic pump (type 7 MHRE; Watson Marlow).

Quantitative estimation of polysaccharide. Strains were grown either in batch culture or on solid King's B media covered with cellophane. Following incubation $(60 \mathrm{~h})$ the cells were recovered from solid media by scraping them off with a glass spreading rod and were suspended in phosphate buffer $\mathrm{pH} 7 \cdot 0$. Cell-free supernatants were then produced from both liquid-cultured and solid-cultured cells by centrifugation $\left(15 \mathrm{~min} ; 10000 \mathrm{~g}_{\mathrm{av}} ; 4^{\circ} \mathrm{C}\right)$. 
Exopolysaccharides were precipitated by adding 3 vol. chilled $\left(\sim 4{ }^{\circ} \mathrm{C}\right)$ propan-2-ol, ethanol or acetone to the chilled cell-free supernatants and desalted by dialysis against distilled water for $24 \mathrm{~h}$ at $4{ }^{\circ} \mathrm{C}$. The dialysis tubing was pretreated by repeated washings in a $0.01 \mathrm{~m}-\mathrm{EDTA} / 1 \%(\mathrm{w} / \mathrm{v}) \mathrm{Na}_{2} \mathrm{CO}_{3}$ solution (Williams, 1974). Samples were dried under reduced pressure over $\mathrm{P}_{2} \mathrm{O}_{5}$ before weighing.

Analytical methods. EP concentration of dialysed supernatants was determined by the phenol-sulphuric acid method of Dubois et al. (1956) using glucose or glucuronic acid as standards. Absorbance readings were taken at $488 \mathrm{~nm}$ for glucose and $482 \mathrm{~nm}$ for glucuronic acid. Uronic acid concentrations in the polysaccharide samples were evaluated by the carbazole method (Bitter \& Muir, 1962) using glucuronic acid as a standard. $O$-Acetyl content of uronic acid polymers was determined by the hydroxamic acid reaction (Weissman \& Meyer, 1954) with acetylcholine as a standard.

Preparation of LPS. LPS was extracted from washed cells with aqueous phenol (Westphal \& Luderitz, 1954). Approximately $1 \mathrm{~g}$ (dry wt) of bacteria was suspended in $50 \mathrm{ml}$ water and warmed to $65^{\circ} \mathrm{C}$. An equal volume of $90 \%(\mathrm{w} / \mathrm{v})$ aqueous phenol at the same temperature was added and the mixture stirred vigorously for $5 \mathrm{~min}$. The aqueous and phenol phases were separated by centrifugation $\left(3000 \mathrm{~g} ; 30 \mathrm{~min} ; 0^{\circ} \mathrm{C}\right)$. Each layer was collected and dialysed for $48 \mathrm{~h}$ against running tap-water to remove phenol. LPS was isolated by ultra-centrifugation ( $100000 \mathrm{~g}$; $4 \mathrm{~h}$ ), purified by Sepharose Cl-4B (Pharmacia) gel filtration (Romanowska, 1970) and dried under reduced pressure over $\mathrm{P}_{2} \mathrm{O}_{5}$

Polysaccharide hydrolysis. EP and LPS glycosidic linkages were hydrolysed by four methods, depending upon subsequent chromatography and the nature of the polymer. (1) Uronic acid polymers were hydrolysed for paper chromatography in $88 \%(\mathrm{v} / \mathrm{v})$ formic acid $\left(5 \mathrm{mg} \mathrm{ml}^{-1} ; 100^{\circ} \mathrm{C} ; 5 \mathrm{~h}\right)$. (2) For GLC analysis the uronic acids in the EP were reduced to primary alcohols while they were still part of the EP. Uronic acids as monomers are difficult to reduce quantitatively to the corresponding neutral carbohydrates, even with repeated treatments with $\mathrm{NaBH}_{4}$ (Sjostrom et al., 1974). However, when they form part of the polymer, the uronic acids can be reduced quantitatively with one treatment with $\mathrm{NaBH}_{4}$ provided the methyl ester is formed first (Smith, 1967). Methyl ester formation, reduction by $\mathrm{NaBH}_{4}$ and hydrolysis in $2 \mathrm{M}-\mathrm{HCl}$ was carried out by the method outlined by Fazio et al. (1982). GLC derivatives were then prepared as for neutral sugars. (3) Polysaccharides containing neutral sugars and hexosamines were hydrolysed in $1 \mathrm{M}-\mathrm{H}_{2} \mathrm{SO}_{4}\left(5 \mathrm{mg} \mathrm{ml}{ }^{-1} ; 100{ }^{\circ} \mathrm{C} ; 16 \mathrm{~h}\right)$. Sulphuric acid was then neutralized by the addition of barium carbonate (saturated solution) and the neutral supernatant containing the sugars was dried at $40^{\circ} \mathrm{C}$ in an evaporator (Evapo-mix, Bucher Instruments, U.S.A.). (4) LPS were hydrolysed in a $40 \%(\mathrm{w} / \mathrm{v})$ suspension of Dowex $50 \mathrm{w}-\mathrm{X} 8\left(\mathrm{H}^{+}\right)$resin $(\mathrm{Sigma})$ in $0.02 \mathrm{M}-\mathrm{HCl}\left(5 \mathrm{mg} \mathrm{ml}^{-1} ; 100{ }^{\circ} \mathrm{C} ; 30 \mathrm{~h}\right)$. The hydrolysate was deaminated using the method outlined by Varma \& Varma (1976). A freshly prepared solution of sodium nitrite $(23.3 \%, \mathrm{w} / \mathrm{v} ; 0.15 \mathrm{ml})$ was added to $0.5 \mathrm{ml}$ of hydrolysate in a sealed glass tube and subjected to intermittent vortexing at room temperature for $30 \mathrm{~min}$. Then, the hydrolysate was neutralized in a tandem exchange column containing $5 \mathrm{ml}$ Dowex $50 \mathrm{w}$-X8 $\left(\mathrm{H}^{+}\right)$over $5 \mathrm{ml}$ Dowex $1-2 \mathrm{X}\left(\mathrm{HCO}_{3}^{-}\right)$. Eluate and washings were collected and fatty acids removed by adding an equal volume of hexane and discarding the upper layer after brief shaking. After this extraction was repeated two to three times the aqueous layer was dried in a rotary evaporator (Rotavapor-RE/A, Orme Scientific) at room temperature.

Paper chromatography. Descending paper-chromatography was on Whatman no. 1 paper irrigated in either butan-1-ol/pyridine/water (6:4:3, by vol.) for neutral sugars (Whistler \& Conrad, 1954) or in acetone/ethanol/isopropanol/0.005 M-borate buffer pH 12 (3:1:1:2, by vol.) for uronic acids (Evans \& Linker, 1973; Mukerjee, 1964). The monosaccharides were detected with aniline phthalate spray reagent (Block et al., 1958).

GLC. GLC of neutral and amino sugars was carried out using either alditol acetate (AA) derivatives (alginate polymers) or peracetylated aldononitrile (PAAN) derivatives.

Derivatization to $A A$ derivatives. Neutralized hydrolysates were reduced to alditols in $\mathrm{NaBH}_{4}\left(10 \mathrm{mg} \mathrm{ml}^{-1}\right)$ for $1 \mathrm{~h}$. Excess $\mathrm{NaBH}_{4}$ was then destroyed by acidifying the samples with acetic acid, and the samples were dried in an evaporator at $40^{\circ} \mathrm{C}$, as for the neutralized supernatants. Methanolic $\mathrm{HCl}(1 \%, \mathrm{v} / \mathrm{v})$ in three $1 \mathrm{ml}$ portions was added, and the contents were dried again after each addition to remove the borate ions quantitatively. The residue was then dissolved in acetic anhydride/dry pyridine $(1: 1, \mathrm{v} / \mathrm{v})$ and heated for $3 \mathrm{~h}$ at $100{ }^{\circ} \mathrm{C}$. The pyridine was extracted with a stream of nitrogen and the residue transferred to chloroform (Sloneker, 1972). GLC analysis was carried out on a Pye series 104 chromatograph model 64 with dual flame ionization detectors, using a column $(175 \times 0.4 \mathrm{~cm})$ of $3 \%(\mathrm{w} / \mathrm{w}) \mathrm{OV}-225$ on Chromosorb W(HP) (with $\mathrm{N}_{2}$ carrier gas at a flow rate of $40 \mathrm{ml} \mathrm{min}^{-1}$ ) maintained isothermally at $195^{\circ} \mathrm{C}$. The peak areas were computed by a Hewlett Packard $3380 \mathrm{~A}$ integrator. Components were identified by their respective retention times in comparison with authentic standards (BDH).

Derivatization to PAAN derivatives. Dried hydrolysates were subjected to successive treatments with (1) 6-7 mg hydroxylamine hydrochloride in $0.4 \mathrm{ml}$ dry pyridine at $100{ }^{\circ} \mathrm{C}$ for $4 \mathrm{~min}$, and (2) $0.5 \mathrm{ml}$ acetic anhydride at $100{ }^{\circ} \mathrm{C}$ for $10 \mathrm{~min}$. The solvents were evaporated, the PAAN derivatives partitioned against chloroform/water $(2: 1, \mathrm{v} / \mathrm{v})$ and the chloroform layer retained for analysis. PAAN derivatives were analysed using a modification of the GLC conditions described by Linton \& Cripps (1978) on Sigma 3 chromatograph model with a single flame ionization detector. Column materials and conditions were the same as for the AA derivatives and components were 
identified by their respective retention times in comparison with the standard sugars derivatized using the procedure outlined for the hydrolysates.

Isolation of outer membranes. Whole cell-membranes were prepared using a method similar to that of Schnaitman (1970). The cells were harvested from batch cultures by centrifugation and washed three times in chilled $0.1 \mathrm{M}$-Tris buffer $\mathrm{pH} 7.8$, containing $0.1 \mathrm{~mm}$-EDTA. The cells were then resuspended in the Tris/EDTA buffer $(30 \mathrm{ml})$, and DNAase I (1 mg) and RNAase A (1 mg) (Sigma) were added to each suspension. The suspensions were cooled to $0{ }^{\circ} \mathrm{C}$ in ice and passed through a French pressure cell (Aminco) three times at 96 $110 \mathrm{MPa}$, followed by the addition of $\mathrm{MgCl}_{2}$ to a final concentration of $2 \mathrm{mM}$. Unbroken cells were then removed by centrifugation $(5000 \mathrm{~g} ; 10 \mathrm{~min})$ and membranes were harvested by further centrifugation $(25000 \mathrm{~g} ; 1 \mathrm{~h})$ and washed three times in $0.01 \mathrm{M}$-Tris/ $\mathrm{HCl}$ buffer $\mathrm{pH} 7.4$ by repeated centrifugation $(25000 \mathrm{~g} ; 1 \mathrm{~h})$.

Outer membranes were separated from the inner membranes by in situ density gradient centrifugation using Percoll density gradient media (Pharmacia). An iso-osmotic stock solution of Percoll was made by addition of 9 parts Percoll to 1 part $2.5 \mathrm{M}$-sucrose and this was further diluted in $0.25 \mathrm{M}$-sucrose $(25 \%, \mathrm{v} / \mathrm{v}$ Percoll stock solution) to give a starting density of $1.06 \mathrm{~g} \mathrm{ml}^{-1}$. The whole-membrane sample $(0.5 \mathrm{ml})$ was then mixed with the Percoll/sucrose medium $(39.5 \mathrm{ml})$ and a balance tube containing density marker beads (Pharmacia) was used to monitor the gradient. The centrifugation was performed in an angle-head rotor $\left(34^{\circ} \mathrm{C} ; 8 \times 50 \mathrm{ml} ; \mathrm{Beckman}\right.$ centrifuge) for $2 \mathrm{~h}$ at $31000 \mathrm{~g}_{\mathrm{av}}$. Under these conditions the inner and outer membranes were separated efficiently to either end of the tube and were easily recovered (inner-membrane density $<1.037 \mathrm{~g} \mathrm{ml}^{-1}$, outer-membrane density $>1.067,<1.081 \mathrm{~g} \mathrm{~m}^{-1}$ ). The membranes were recovered from the Percoll media on a $1.4 \times 70 \mathrm{~cm}$ column of Sepharose $\mathrm{Cl}-2 \mathrm{~B}$, equilibrated with $0.01 \mathrm{M}-\mathrm{Tris} / \mathrm{HCl} \mathrm{pH} 7.4$ at $4{ }^{\circ} \mathrm{C}$, and the void volume fraction was concentrated in an Amicon ultrafiltration system (YM10 membrane).

Electrophoresis of outer-membrane proteins. Acrylamide-bisacrylamide (BDH) slab gels were prepared using the discontinuous buffer system described by Laemmli (1970). The stacking gel contained $4 \%(\mathrm{w} / \mathrm{v})$ acrylamide in the presence of $0.125 \mathrm{M}$-Tris $/ \mathrm{HCl}, \mathrm{pH} 6.8$, and $0.1 \% \mathrm{SDS}$. The resolving gel contained $8 \%(\mathrm{w} / \mathrm{v})$ acrylamide in the presence of $0.375 \mathrm{M}$-Tris $/ \mathrm{HCl}, \mathrm{pH} 8.8$, and $0.1 \%$ SDS. Ammonium persulphate and $\mathrm{N}, \mathrm{N}, \mathrm{N}^{\prime}, \mathrm{N}^{\prime}$-tetramethylethylenediamine (Sigma) were used as polymerizing agents, and the running buffer (pH 8.3) contained $0.025 \mathrm{M}$-Tris base, $0.192 \mathrm{M}$-glycine and $1.0 \%(\mathrm{w} / \mathrm{v})$ SDS. The gels were prepared by the method of Ames (1974) and were run at a constant current of $40 \mathrm{~mA}$ with the voltage increasing from $80 \mathrm{~V}$ to $200 \mathrm{~V}$ and the run lasting about $4 \cdot 5 \mathrm{~h}$. When run, the gels were stained by the four staining steps recommended by Fairbanks et al. (1971) using Page blue G83 (Sigma; $0.1 \%$ ) in propan-2-ol and acetic acid. Finally the gels were dried to filter paper.

Attachment assay. The assay of attachment of wild-type and adhesion mutants to polystyrene substrata was based on a method previously described by Fletcher (1977). Cells were harvested by centrifugation, resuspended in phosphate buffer $\mathrm{pH} 7 \cdot 4(0.05 \mathrm{M})$ to an absorbance $(540 \mathrm{~nm})$ of $0 \cdot 2$. Portions $(5 \mathrm{ml})$ of bacterial suspensions were placed in either hydrophobic polystyrene petri dishes $(3 \mathrm{~cm}$ diam.; Sterilin) or hydrophilic polystyrene tissue culture dishes ( $3 \mathrm{~cm}$ diam.; Costar) and allowed to attach for $2 \mathrm{~h}$. Suspended cells and loosely adsorbed bacteria were removed from the petri dish surface by rinsing (four times) with phosphate buffer. The remaining cells were then fixed with Bouin's fixative and stained with crystal violet. Attached cell numbers were evaluated by measuring the absorbance $(590 \mathrm{~nm})$ of each dish surface at 4 randomly chosen areas. Duplicate dishes were used for each attachment assay condition.

\section{RESULTS}

\section{The selection and enrichment of adhesion mutants during the continuous culture of wild-type}

\section{$P$. fluorescens}

The operation of the continuous culture system was found to select and enrich for two types of adhesion mutants by the foam fractionation of wild-type cells during the initial continuous culture phase $(6 \mathrm{~d})$. The results in Fig. 3 show the changes in viable counts of wild-type and mucoid mutants during the operation of the continuous culture system, with the dilution rate and EP level detected in the media. It shows the rapid removal of wild-type cells following the initial batch culture and a repeat of this process following the return of cells during a second period of batch culture. Once continuous culture conditions were established, the viable counts of both wild-type and mucoid colonies showed a 'take-over' of the culture by the mucoid mutant which coincided with the production of EP, detectable in the culture medium.

After $17 \mathrm{~d}$ culture, the distribution of colony morphologies was determined from samples of the aqueous phase and walls of the fermenter. The results in Table 1 show the viable counts of these samples and the ratios of the mutants to wild-type colonies. Wild-type colonies were just detectable in samples from the aqueous phase, which was dominated by the mucoid mutant. 


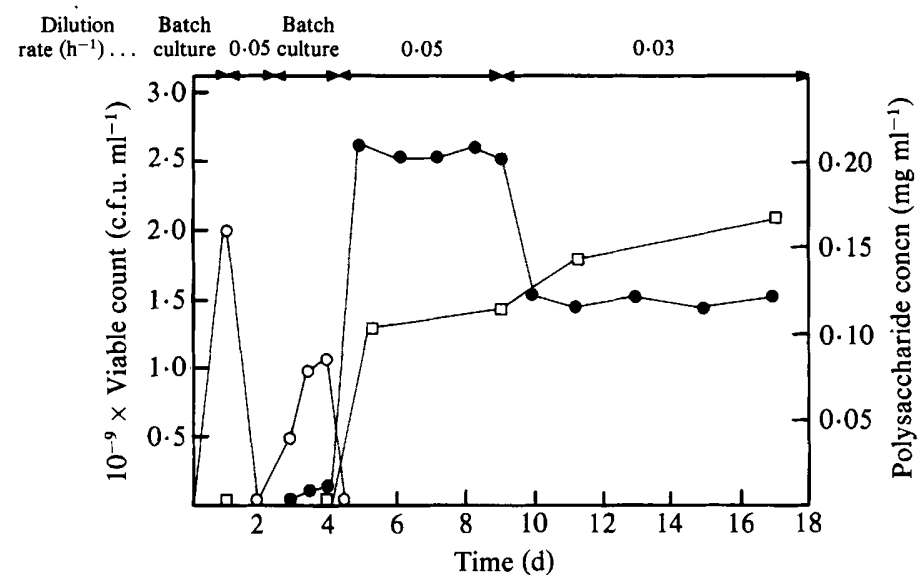

Fig. 3. The change in viable counts of wild-type $(O)$ and a mucoid mutation $(O)$ and in EP concentration ( $\square$ ) during batch and continuous culture of $P$. fluorescens.

Table 1. Distribution of the colony morphology sampled from the bulk liquid and fermenter walls after $17 d$ continuous culture

$\begin{array}{llrc}\begin{array}{c}\text { Colony } \\ \text { morphology }\end{array} & \text { Sample site* } & \begin{array}{c}\text { Viable count } \\ \text { (c.f.u. } \mathrm{ml}^{-1} \text { ) }\end{array} & \begin{array}{c}\text { Mutants:wild-type } \\ \text { ratio }\end{array} \\ \text { Wild-type } & \text { Bulk liquid } & <1.0 \times 10^{5} & - \\ \text { Mucoid } & \text { Bulk liquid } & 4.8 \times 10^{8} & >4800 \\ \text { Crenated } & \text { Bulk liquid } & 2.0 \times 10^{6} & >20 \\ \text { Wild-type } & \text { Fermenter walls } & 2.3 \times 10^{8} \dagger & - \\ \text { Mucoid } & \text { Fermenter walls } & 3.0 \times 10^{6} \dagger & 0.013 \\ \text { Crenated } & \text { Fermenter walls } & 8.6 \times 10^{8} \dagger & 3.7 \\ & & \end{array}$

However, the crenated morphology was dominant in the wall population, with a smaller population of wild-type colonies and only detectable levels of mucoid mutants.

In order to confirm that the changes in colony morphology were due to mutation of the wildtype and not contaminants, the sensitivity of a number of colonies of each mutant type to 12 antibiotics was checked and all mutant strains tested showed similar sensitivity patterns to those of the wild-type. However, although the wild-type was found to be resistant to carbenicillin, enhanced carbenicillin resistance was found for all mucoid strains examined. The crenated mutants studied were all phenotypically similar and no spontaneous reversion to the wild-type condition occurred. However, the mucoid strains showed a high frequency of reversion to the wild-type colony appearance.

\section{Attachment assays of wild-type and adhesion mutants}

In order to confirm that the mutations were affecting the attachment ability of the bacterium, the attachment properties of several strains of each mutant were examined. The attachment assay used hydrophilic and hydrophobic polystyrene petri dishes as test substrata, and attachment was assessed quantitatively by staining the attached bacterial films in crystal violet and measuring the absorbance of this stained film. The results in Table 2 show the attachment results of each mutant type, as compared to the wild-type, for both substrata. The results confirm the fermenter findings in that mucoid mutants (H2M1, H2M2) showed lower levels of attached cells than the wild-type, and the crenated mutants (H2S1, H2S2) showed greater levels of attached cells. 
Table 2. Attachment of adhesion mutants to polystyrene and tissue culture polystyrene Petri dishes following growth in carbon-limited batch culture

$\begin{array}{llll}\text { Strain no. } & \text { Cell type } & \overbrace{}^{\text {Polystyrene }} & \begin{array}{c}\text { Tissue culture } \\ \text { polystyrene }\end{array} \\ \text { H2P } & \text { Wild-type } & 0.190(0.022) & 0.067(0.007) \\ \text { H2M1 } & \text { Mucoid } \dagger & 0.025(0.003) & 0.011(0.005) \\ \text { H2M2 } & \text { Mucoid } \dagger & 0.051(0.005) & 0.018(0.005) \\ \text { H2S1 } & \text { Crenated } & 0.216(0.022) & 0.094(0.005) \\ \text { H2S2 } & \text { Crenated } & 0.252(0.034) & 0.126(0.007)\end{array}$

* Numbers in parentheses are sample s.D.s $\left(\sigma_{\mathrm{n}-1}\right)$, where $\mathrm{n}=8$.

$\dagger$ The mucoid mutation is unstable in batch culture, and reversion rate can be high, dependent upon growth conditions. Thus, cultures may contain significant numbers of cells with wild-type morphology.

Characterization of the outer cell-surface of wild-type and adhesion mutants

Comparisons of outer-membrane proteins (isolated by equilibrium density gradient centrifugation and separated by SDS-PAGE are shown (Figs 4 and 5). The major proteins, labelled I, II, III, and IV, were present in all strains examined; however, there was a significant

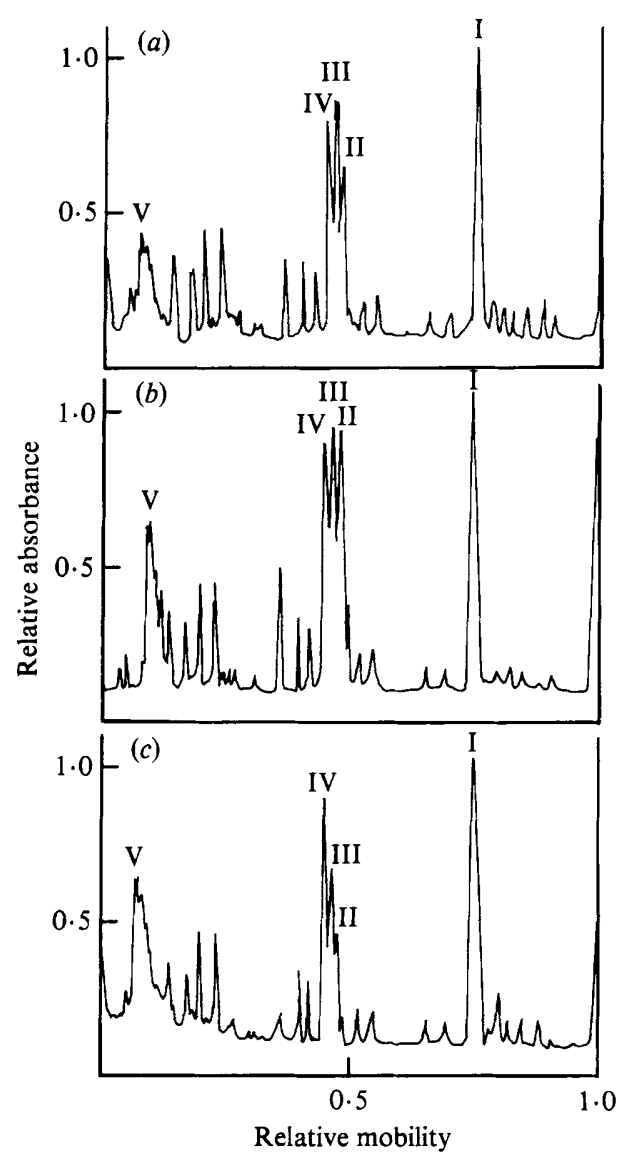

Fig. 4. Laser densitometer scan of outer-membrane proteins of $(a)$ the wild-type, $(b)$ crenated mutant $\mathrm{H} 2 \mathrm{~S} 1$, and (c) mucoid mutant H2M1. The major proteins, labelled I, II, III, IV and V, were present in all strains examined, but their relative proportions differed. 


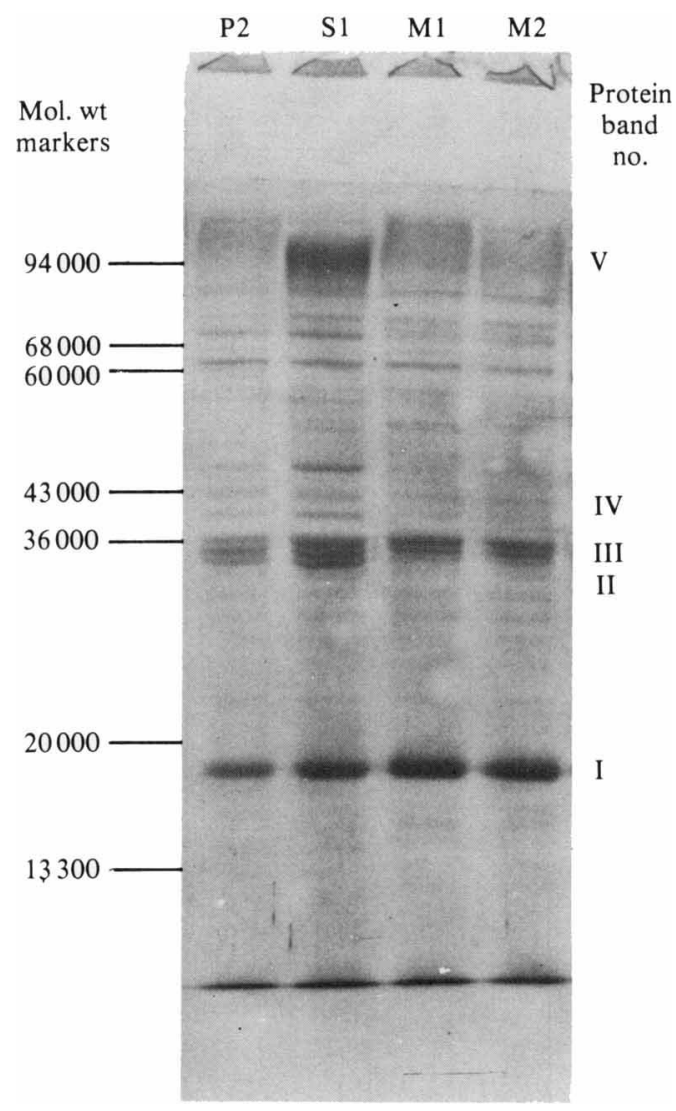

Fig. 5. Electrophoresis of outer-membrane fractions from wild-type (P2), a crenated mutant (S1) and two mucoid mutants (M1, M2).

loss of smaller bands from the crenated strains, accompanied by a change in mobility of a diffuse staining region labelled $\mathrm{V}$. The mucoid electropherogram was similar to that of the wild-type except for small changes in the minor bands. The LPS-protein complex characteristic of outer membranes was found to have the same mobility as the marker dye bromophenol blue and was demonstrated using periodic acid-Schiff staining.

The results in Table 3 show the yields of LPS and EP from the wild-type and mutant strains. The results indicate that the crenated mutants $\mathrm{H} 2 \mathrm{~S} 1$ and $\mathrm{H} 2 \mathrm{~S} 2$ had $40-55 \%$ less polysaccharide

Table 3. Lipopolysaccharide (LPS) and exopolysaccharide (EP) yields from P. fluorescens strains

\section{Yield of}

Strain

Yield of crude LPS lipid-free polysaccharide Yield of crude EP (percentage of cell dry wt) (percentage by wt of LPS) (percentage of cell dry wt)

H2P2 (wild-type)

H2M1 (mucoid)

H2M2 (mucoid)

$\mathrm{H} 2 \mathrm{~S} 1$ (crenated)

$\mathrm{H} 2 \mathrm{~S} 2$ (crenated)

$\begin{array}{ll}2 \cdot 9 & 17 \cdot 3 \\ 2 \cdot 4 & 19 \cdot 4 \\ 2 \cdot 3 & 20 \cdot 2 \\ 2 \cdot 0 & 15 \cdot 4 \\ 1 \cdot 6 & 13 \cdot 8\end{array}$

$1 \cdot 3$

$50 \cdot 7$

$173 \cdot 0$

0.9

0.9 
in the LPS as compared to the wild-type and mucoid strains. Also, only the mucoid strains $\mathrm{H} 2 \mathrm{M} 1$ and $\mathrm{H} 2 \mathrm{M} 2$ produced significant amounts of EP.

\section{LPS analysis}

LPS of each strain was analysed in order to determine whether changes in the mutant characteristics could be attributed to differences in LPS composition. The sugars in the polysaccharide fraction of the LPS were analysed as their respective PAAN derivatives. Amino sugars were deaminated, following resin-catalysed hydrolysis, to anhydroaldoses. Glucosamine, galactosamine, quinosamine and fucosamine are deaminated to 2,5-dideoxy-mannose, 2,5dideoxy-talose, 2,5,6-trideoxy-mannose and 2,5,6-trideoxy-talose, respectively, and these were also analysed as their respective PAAN derivatives. It was assumed that the relative proportions of the PAAN derivatives indicated the respective proportions of underivatized sugar in the original material and that the detector response was the same for each PAAN derivative (Seymour et al., 1979).

The polysaccharide from the wild-type and mutant strains consisted predominantly of glucose $(25-30 \%)$, ribose $(21-24 \%)$, dideoxyhexosamines $(29-33 \%)$, rhamnose $(11-15 \%)$ and glucosamine $(4-6 \%)$. However, no significant differences were found between mutant types and the wild-type.

Significant amounts of ribose were detected in each strain studied, but this could have been due to extensive contamination of LPS extracts with nucleic acids. Although LPS extracts were purified by gel filtration, no significant amounts of 2-deoxyribose were detected and all strains examined showed consistent amounts of ribose present.

\section{EP analysis}

The EP from the wild-type and crenated mutant was difficult to precipitate with ice-cold isopropanol and formed a granular precipitate which could only be removed by centrifugation. The composition of the EP from these strains (Table 4) was found to be predominantly sugars thought to be specific to the LPS composition (see above).

Paper chromatography of hydrolysed polymers from mucoid strains revealed a pure uronic acid polymer composed of D-mannuronic acid with variable amounts of its 5 -epimer, Lguluronic acid. With all mucoid strains tested, $O$-acetyl groups were present at concentrations between $5-10 \%(\mathrm{w} / \mathrm{w})$ of total EP, as calibrated against the standard. Table 4 contains values of mannuronic acid and guluronic acid as mannose and glucose/gulose derivatives, respectively, as the reduced derivatives of the uronic acids have the same retention times as their analogous sugars. These values are similar to the carbazole values calculated as percentage of dry weight and based on a glucuronic acid standard.

\section{Table 4. Analysis of exopolysaccharide from P. fluorescens strains}

Values of each derivative are expressed as a percentage of the total carbohydrate

Strain Mannose Glucose/Gulose Ribose Rhamnose Glucosamine Galactosamine Dideoxyhexosamine

\begin{tabular}{|c|c|c|c|c|c|c|c|}
\hline $\begin{array}{l}\text { H2P2 } \\
\text { (wild-type) }\end{array}$ & $2 \cdot 7$ & $27 \cdot 7$ & $20 \cdot 3$ & $15 \cdot 0$ & $3 \cdot 4$ & Trace & $30 \cdot 9$ \\
\hline $\begin{array}{l}\mathrm{H} 2 \mathrm{~S} \text { l } \\
\text { (crenated) }\end{array}$ & $2 \cdot 3$ & $30 \cdot 1$ & $23 \cdot 0$ & $10 \cdot 7$ & $4 \cdot 6$ & Trace & $29 \cdot 3$ \\
\hline $\begin{array}{l}\mathrm{H} 2 \mathrm{~S} 2 \\
\text { (crenated) }\end{array}$ & $2 \cdot 3$ & $30 \cdot 4$ & $21 \cdot 6$ & $11 \cdot 6$ & $3 \cdot 0$ & Trace & $31 \cdot 1$ \\
\hline $\begin{array}{l}\mathrm{H} 2 \mathrm{M} 1 \\
\text { (mucoid) }\end{array}$ & $56 \cdot 8^{*}$ & $43 \cdot 2^{*}$ & Trace & Trace & - & - & Trace \\
\hline $\begin{array}{l}\text { H2M2 } \\
\text { (mucoid) }\end{array}$ & $85 \cdot 6^{*}$ & $14 \cdot 4^{*}$ & Trace & Trace & - & - & Trace \\
\hline
\end{tabular}

* Alditol acetate derivatives of mannuronic acid and guluronic acid following methyl ester formation and reduction with $\mathrm{NaBH}_{4}$. 


\section{DISCUSSION}

The collection of microbial cells by foam fractionation was first demonstrated by Dognon (1941), who found that Mycobacterium tuberculosis cells were easily removed from suspension by foaming, while Escherichia coli, Staphylococcus albus and Schizosaccharomyces sp. were concentrated with difficulty. Boyles \& Lincoln (1958) found that the nature of the bacterial surface affected the collection efficiency, and hydrophilic smooth strains of Brucella suis were not concentrated in foam under numerous conditions, whereas hydrophobic rough strains were effectively concentrated. The hydrophobic interactions of bacteria have also been examined in marine environments in studies of the air/liquid interface using hydrophobic interaction chromatography (HIC) (Dahlbäck et al., 1981) and dodecanoic acid binding (Kjelleberg et al., 1980). These studies showed that the initial adhesion of bacteria to the surface microlayer depended in part on hydrophobic interactions.

Previous adhesion studies of wild-type strains of this organism indicated that the cells are able to enter into hydrophobic interactions with surfaces (Pringle \& Fletcher, 1982), and this was confirmed by their foam fractionation properties.

In this study the incorporation of foam fractionation into the basic fermenter design using the gas entrainment principle removed a large proportion of the wild-type cells from the fermenter. Foam fractionation has been reported to concentrate bacteria cells $10^{6}$-fold (Grieves \& Wang, 1966); however, total counts of this organism showed $10^{3}$-fold concentration after $2 \mathrm{~h}$ operation. This property was also found for Pseudomonas aeruginosa NCIB 8602 which, like $P$. fluorescens produced mucoid and crenated mutations, but no significant fractionation of an Aeromonas hydrophila strain was detected (J. H. Pringle, unpublished results). Further studies may reveal how common foam fractionation is in natural populations.

\section{Selection and enrichment of adhesion mutants}

The mucoid exopolysaccharide-producing mutant dominated the aqueous phase, as it was not removed by foam fractionation. The crenated mutant, on the other hand, dominated the fermenter walls (Table 1) as it had a greater attachment ability, confirmed by attachment assay (Table 2). In studies of wall growth or adhesion in mixed bacterial cultures using chemostats, little attention has been paid to changes in the cell surface characteristics reflected by colony morphology. However, Brown et al. (1977) have reported that differences in attachment levels in mixed population were related to the presence or absence of a glucose-containing polysaccharide. When the chemostat was supplied with glucose-limited medium, a wide variety of bacterial types was found attached but no surface polymer was apparent. In nitrogen-limited medium the culture contained an abundance of extracellular polymer and little cell adhesion. In similar enrichment studies, Wardell et al. (1980) confirmed that non-specific attachment occurred in C-limited cultures without the appearance of either large amounts of polymer or specific appendages. These results together with this study indicate that mucoid EP, originally thought to act as cell adhesives, when present in an environment may either inhibit the initial cell attachment to solid surfaces, possibly by ionic repulsion or steric hindrance (Pethica, 1961), or saturate all available cell binding sites by adsorption on to the surface. Further work is required into the adsorption isotherms of these polymers to test substrata.

The role of outer-membrane proteins in adhesion is unclear, although small differences were detectable in SDS-polyacrylamide gels of outer-membrane proteins from the wild-type and adhesion mutants. No significant changes in major outer-membrane bands could be seen. Further studies of the extrinsic proteins would show to what extent these components influence the characteristics of the membrane surface. The results of the LPS analysis suggested that the crenated mutants were similar to the crenated (CR) mutants of Klebsiella (Norval \& Sutherland, 1969), as in liquid media both mutants auto-agglutinated due to reduced LPS content (in this case between 30-55\%). However, these mutants differed from Salmonella semi-rough (SR) mutants which have polymer with side-chains containing a single oligosaccharide repeating unit (Luderitz et al., 1971).

To what extent changes in LPS influence the hydrophobicity of the cell surface may be important in cell adhesion to solid surfaces. Magnusson et al. (1977) demonstrated changes in 
cell hydrophobicity and charge interaction using an aqueous polymer two-phase system to compare smooth and rough Salmonella typhimurium and LPS. The rough Rd mutant of $S$. typhimurium showed hydrophobic interaction with covalently linked hydrophobic groups in the aqueous polymer system, indicating a number of accessible sites at the cell surface. By contrast the smooth (S) bacteria and LPS from the parent strain did not participate in hydrophobic or charge interactions, indicating extensive surface hydrophilicity and charge. Changes in the LPS content undoubtedly change the coverage of the cell surface by the polysaccharide side chains of LPS. In wild-type strains of $E$. coli or $S$. typhimurium, the cell surface is effectively covered by such chains, estimated at $41 \%$ of the outer-surface area. However, rough mutants reduce this coverage to only $8 \%$, leaving many of the surface proteins and lipids exposed (Nikaido \& Nakae, 1980).

Finally the results of the attachment assay and the investigation of attachment mutants suggested that polyanionic carbohydrate slimes, produced by many aquatic organisms, may not participate in the initial non-specific attachment to the hydrophobic solid/liquid interface as previously suggested (Corpe, 1974; Costerton et al., 1978). The abundant acidic polysaccharide materials described by Corpe (1970) may not be concerned with the primary attachment of the producing cells, but with the development of subsequent bacterial film, a process requiring timedependent biosynthesis and the formation of cell-to-cell bridges. These results also demonstrated the role of changes in the surface of bacteria on their interactions at interfaces, which are important in both in the natural environment and in fermentation technology.

The excellent technical assistance of $\mathbf{L}$. Richardson is gratefully acknowledged. The work was supported by a Science and Engineering Research Council CASE Studentship.

\section{REFERENCES}

AMEs, G. F. L. (1974). Resolution of bacterial proteins by polyacrylamide gel electrophoresis on slabs. Journal of Biological Chemistry 249, 634-644.

BitTer, T. \& MUIR, H. M. (1962). A modified uronic acid carbazole reaction. Analytical Biochemistry 4, 330-334.

Block, R. J., Durrum, E. L. \& ZweiG, G. (1958). A Manual of Paper Chromatography and Paper Electrophoresis. New York: Academic Press.

Boyles, W. A. \& Lincoln, R. E. (1958). Separation and concentration of bacterial spores and vegetative cells by foam flotation. Applied Microbiology 6, 327334.

Brown, C. M., Ellwood, D. C. \& Hunter, J. R. (1977). Growth of bacteria at surfaces: influence of nutrient limitation. FEMS Microbiology Letters 1, 163-166.

CORPE, W. A. (1970). An acid polysaccharide produced by a primary film-forming bacterium. Developments in Industrial Microbiology 2, 402-412.

CORPE, W. A. (1974). Periphytic marine bacteria in the formation of microbial film on solid surfaces. In Effects of the Ocean Environments on Microbial Activities, pp. 397-417. Edited by R. Colwell \& R. Morita. Baltimore: University Park Press.

CORPE, W. A. (1979). Microbial surface components involved in adsorption of microorganisms onto surfaces. In Adsorption of Microorganisms to Surfaces, pp. 106-139. Edited by G. Bitton \& K. C. Marshall. New York: Wiley.

Costerton, J. W., Geesey, G. G. \& Cheng, K. J. (1978). How bacteria stick. Scientific American 238, 86-95.

DahlbäcK, B., Hermansson, M., KJelleberg, S. \&
NoRkRANS, B. (1981). The hydrophobicity of bacteria - an important factor in their adhesion at the air-water interface. Archives of Microbiology 128, 267-270.

Dazzo, F. B. (1980). Microbial adhesion to plant surfaces. In Microbial Adhesion to Surfaces, pp. 311328. Edited by R. C. W. Berkeley, J. M. Lynch, J. Melling, P. R. Rutter \& B. Vincent. Chichester: Ellis Horwood.

Dognon, A. (1941). Concentrating and separating molecules and particles by means of froth formation. Reviews of Science (France) 79, 613-619.

Dubois, M., Gilles, K. A., Hamilton, J. K., Rebers, P. A. \& SMITH, F. (1956). Colorimetric method for the determination of sugars and related substances. Analytical Chemistry 28, 350-356.

Evans, L. R. \& Linker, A. (1973). Production and characterisation of the slime polysaccharide of Pseudomonas aeruginosa. Journal of Bacteriology 116 , 915-924.

Fairbanks, G., Steck, T. L. \& Wallach, D. F. H. (1971). Electrophoretic analysis of the major polypeptides of the human erythrocyte membrane. Biochemistry 10, 2606-2617.

Fazio, S. A., Uhlinger, D. J., Parker, J. H. \& WhITE, D. C. (1982). Estimation of uronic acids as quantitative measures of extracellular and cell wall polysaccharide polymers from environmental samples. Applied and Environmental Microbiology 43, 1151-1159.

FLETCHER, M. (1977). The effects of culture concentration and age, time and temperature on bacterial attachment to polystyrene. Canadian Journal of Microbiology 23, $1-6$. 
Fletcher, M. \& Floodgate, G. D. (1973). An electron-microscopic demonstration of an acidic polysaccharide involved in the adhesion of a marine bacterium to solid surfaces. Journal of General Microbiology 74, 325-334.

GibBons, R. J. \& VAN Houte, J. (1980). Bacterial adherence and the formation of dental plaques. In Bacterial Adherence (Receptors and Recognition, series B, vol. 6), pp. 61-104. Edited by E. H. Beachey. London \& New York: Chapman \& Hall.

GrIEVES, R. B. \& WANG, S. (1966). Foam separation of Escherichia coli with a cationic surfactant. Biotechnology and Bioengineering 8, 323-336.

Haynes, W. C. \& Rhodes, L. J. (1962). Comparative taxonomy of crystallo-genic strains of Pseudomonas aeruginosa and Pseudomonas chlororaphis. Journal of Bacteriology 84, 1080-1084.

Hendrie, M. S. \& Shewan, J. M. (1979). The identification of pseudomonads. In Indentification Methods for Microbiologists, pp. 1-12. Edited by F. A. Skinner \& D. W. Lovelock. London: Academic Press.

Hollo, J., Toth, J., Tengerdy, R. P. \& Johnson, J. E. (1979). Denitrification and removal of heavy metals from waste water by immobilised microorganisms. In Immobilized Microbial Cells, Symposium Series vol. 106, pp. 73-84. Edited by K. Ventkatasubramanian. Washington, D. C.: American Chemical Society.

KARGER, B. L. (1967). Nomenclature recommendations for adsorptive bubble separation methods. Separation Science 2, 401-404.

KING, A. \& Phillips, I. (1978). The identification of pseudomonads and related bacteria in a clinical laboratory. Journal of Medical Microbiology 11, 165176.

KING, E. O., WaRD, M. K. \& Raney, D. E. (1954). Two simple media for the demonstration of pyocyanin and fluorescin. Journal of Laboratory and Clinical Medicine 44, 301-307.

KJelleberG, S., LagerCRANTZ, C. \& Larsson, T. H. (1980). Quantitative analysis of bacterial hydrophobicity studied by the binding of dodecanoic acid. FEMS Microbiology Letters 7, 41-44.

Kovács, N. (1956). Identification of Pseudomonas pyocyanea by the oxidase reaction. Nature, London 178, 703.

LAEMMLI, U. K. (1970). Cleavage of structural proteins during the assembly of the head of bacteriophage T4. Nature, London 227, 680-685.

LEMLICH, R. (1966). Adsubble methods. Chemical Engineering 73, 7-12.

LEMLICH, R. (1972). Adsubble processes: foam fractionation and bubble fractionation. Journal of Geophysical Research 77, 5204-5210.

LINTON, J. D. \& CRIPPS, R. E. (1978). The occurrence and identification of intracellular polyglucose storage granules in Methylococcus NCIB 11083 grown in chemostat culture on methane. Archives of Microbiology 117, 41-48.

LipPINCOTT, J. A. \& LiPPINCOTT, B. B. (1980). Microbial adherence in plants. In Bacterial Adherence (Receptors and Recognition, series B, vol. 6), pp. 375-398. Edited by E. H. Beachey. London: Chapman \& Hall.
Lüderitz, O., Westphal, O., Staub, A. M. \& NAKAIDO, H. (1971). Isolation and chemical and immunological characterisation of bacterial lipopolysaccharides. In Microbial Toxins, vol. IV, pp. 145-233. Edited by G. Weinbaum, S. Kadis \& S. J. Ajl. New York \& London: Academic Press.

Magnusson, K. E., Stendahl, O., Tagesson, C., EDEBo, L. \& Johansson, G. (1977). The tendency of smooth and rough Salmonella typhimurium bacteria and lipopolysaccharide to hydrophobic and ionic interaction as studied in aqueous polymer two-phase systems. Acta pathologica et microbiologica scandinavica section B 85, 212-218.

MARSHALL, K. C. (1976). Interfaces in Microbial Ecology. Cambridge, Mass.: Harvard University Press.

Meadows, P. S. \& Anderson, J. G. (1979). The microbiology of interfaces in the marine environment. In Progress in Industrial Microbiology, vol. 15, pp. 207-265. Edited by M. J. Bull. London: Elsevier.

MUKERJEe, H. (1964). A new solvent system for paper chromatographic separation of glucuronic acid and galacturonic acid. Journal of Chromatography 14, $551-552$.

NiKaIDO, H. \& NAKAE, T. (1980). The outer membrane of Gram-negative bacteria. In Microbial Cell Walls and Membranes, pp. 163-250. Edited by $\mathrm{H}$. J. Rogers, H. R. Perkins \& J. B. Ward. London: Chapman \& Hall.

Norval, M. \& Sutherland, I. W. (1969). A group of Klebsiella mutants showing temperature-dependent polysaccharide synthesis. Journal of General Microbiology 57, 369-377.

Palleroni, N. J. \& Doudoroff, M. (1972). Some properties and taxonomic subdivisions of the genus Pseudomonas. Annual Review of Phytopathology 10, 73-100.

PethicA, B. A. (1961). The physical chemistry of cell adhesion. Experimental Cell Research supplement 8, 123-140.

Pringle, J. H. \& Fletcher, M. (1982). Influence of substratum wettability on the attachment of freshwater bacteria to solid surfaces. Applied and Environmental Microbiology 45, 811-817.

ROGERS, H. J. (1980). Adhesion of microorganisms to surfaces: some general considerations of the role of the envelope. In Adhesion of Microorganisms to Surfaces, pp. 29-55. Edited by D. C. Ellwood, J. Melling \& P. Rutter. London: Academic Press.

RomanowSKA, E. (1970). Sepharose gel filtration method of purification of lipopolysaccharides. Analytical Biochemistry 33, 383-389.

Schnatman, C. A. (1970). Protein composition of the cell wall and cytoplasmic membrane of Escherichia coli. Journal of Bacteriology 104, 890-901.

Seymour, F. R., Chen, E. C. M. \& Bishop, S. H. (1979). Identification of aldoses by use of their peracetylated aldononitrile derivatives: a GLC-MS approach. Carbohydrate Research 73, 19-45.

Sjostrom, E., Pfister, K. \& Seppala, E. (1974). Quantitative determination of aldonic and uronic acids by gas chromatography-mass spectrometry. Carbohydrate Research 38, 293-299.

SLONEKER, J. H. (1972). Gas-liquid chromatography of alditol acetates. Methods in Carbohydrate Chemistry 6, 20-24. 
Smith, E. J. (1967). Purification and properties of acidic polysaccharides isolated from Achromobacter georgiopolitanum. Journal of Biological Chemistry 243, 5139-5144.

Stotzky, G. (1980). Surface interactions between clay minerals and microbes, viruses and soluble organics, and the probable importance of these interactions to the ecology of microbes in soil. In Microbial Adhesion to Surfaces, pp. 231-262. Edited by R. C. W. Berkeley, J. M. Lynch, J. Melling, P. R. Rutter \& B. Vincent. Chichester: Ellis Horwood.

Sutherland, I. W. (1980). Polysaccharides in the adhesion of marine and freshwater bacteria. In Microbial Adhesion to Surfaces, pp. 329-338. Edited by R. C. W. Berkeley, J. M. Lynch, J. Melling, P. R. Rutter \& B. Vincent. Chichester: Ellis Horwood.

VARMA, R. \& VARMA, R. S. (1976). Simultaneous determination of neutral sugars and hexosamines in glycoproteins and acid mucopolysaccharides (glycosaminoglycans) by gas-liquid chromatography. Journal of Chromatography 128, 45-52.

VenKatasubramanian, K. \& VieTH, W. R. (1979). Immobilized microbial cells. In Progress in Industrial Microbiology, vol. 15, pp. 61-86. Edited by M. J. Bull. London: Elsevier.

WALKER, P. D. \& NAGY, L. K. (1980). Adhesion of organisms to animal tissues. In Microbial Adhesion to
Surfaces, pp. 473-494. Edited by R. C. W. Berkeley, J. M. Lynch, J. Melling, P. R. Rutter \& B. Vincent. Chichester: Ellis Horwood.

W ARdell, J. N., Brown, C. M. \& Ellwood, D. C. (1980). A continuous culture study of the attachment of bacteria to surfaces. In Microbial Adhesion to Surfaces, pp. 221-230. Edited by R. C. W. Berkeley, J. M. Lynch, J. Melling, P. R. Rutter \& B. Vincent. Chichester: Ellis Horwood.

Weissman, B. \& MEYer, K. (1954). Structure of hyaloburonic acid and hyaluronic acid. Journal of the American Chemical Society 76, 1753-1757.

Westphal, O. \& Lüderitz, O. (1954). Chemische Erforschung von Lipopolysacchariden Gram-negativer Bakterien. Angewandte Chemie 66, 407-417.

Whistler, R. L. \& ConRAD, H. E. (1954). 2-O-(Dgalactopyranosyluronic acid)-L-rhamnose from okra mucilage. Journal of the American Chemical Society 76, 3544-3546.

Williams, A. G. (1974). Extracellular polysaccharide production by a Gram-negative bacterial isolate. Ph.D thesis, University of Wales, U.K.

Williams, A. G. \& WimpenNy, J. W. T. (1976). Exopolysaccharide production by Pseudomonas PB 1 grown in batch and continuous culture. Effect of growth conditions. Journal of Applied Chemistry and Biotechnology 26, 326-327. 